\title{
BMJ Open Risk of myocardial infarction (MI) and death following MI in people with chronic obstructive pulmonary disease (COPD): a systematic review and meta-analysis
}

\author{
Kieran J Rothnie, ${ }^{1,2}$ Ruoling Yan, ${ }^{3}$ Liam Smeeth, ${ }^{2}$ Jennifer K Quint ${ }^{1,2}$
}

To cite: Rothnie KJ, Yan R, Smeeth L, et al. Risk of myocardial infarction (MI) and death following $\mathrm{MI}$ in people with chronic obstructive pulmonary disease (COPD): a systematic review and meta-analysis. BMJ Open 2015;5:e007824. doi:10.1136/bmjopen-2015007824

\section{- Prepublication history} and additional material is available. To view please visit the journal (http://dx.doi.org/ 10.1136/bmjopen-2015007824)

Received 30 January 2015 Revised 6 May 2015 Accepted 17 June 2015

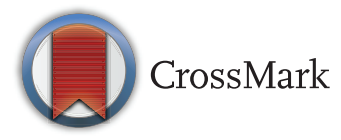

${ }^{1}$ Respiratory Epidemiology, Occupational Medicine and Public Health, National Heart and Lung Institute, Imperial College London, London, UK ${ }^{2}$ Faculty of Epidemiology and Population Health, London School of Hygiene \& Tropical Medicine, London, UK

${ }^{3}$ Medical School, Faculty of Medical Sciences, University College London, London, UK

Correspondence to Kieran J Rothnie;

Kieran.Rothnie@Ishtm.ac.uk

\section{ABSTRACT}

Objectives: Cardiovascular disease is an important comorbidity in patients with chronic obstructive pulmonary disease (COPD). We aimed to systematically review the evidence for: (1) risk of myocardial infarction (MI) in people with COPD; (2) risk of MI associated with acute exacerbation of COPD (AECOPD); (3) risk of death after MI in people with COPD.

Design: Systematic review and meta-analysis. Methods: MEDLINE, EMBASE and SCI were searched up to January 2015. Two reviewers screened abstracts and full text records, extracted data and assessed studies for risk of bias. We used the generic inverse variance method to pool effect estimates, where possible. Evidence was synthesised in a narrative review where meta-analysis was not possible.

Results: Searches yielded 8362 records, and 24 observational studies were included. Meta-analysis showed increased risk of MI associated with COPD (HR $1.72,95 \% \mathrm{Cl} 1.22$ to 2.42 ) for cohort analyses, but not in case-control studies: OR 1.18 (0.80 to 1.76). Both included studies that investigated the risk of MI associated with AECOPD found an increased risk of MI after AECOPD (incidence rate ratios, IRR 2.27, 1.10 to 4.70, and IRR 13.04, 1.71 to 99.7). Meta-analysis showed weak evidence for increased risk of death for patients with COPD in hospital after MI (OR 1.13, 0.97 to 1.31). However, meta-analysis showed an increased risk of death after MI for patients with COPD during follow-up (HR 1.26, 1.13 to 1.40).

Conclusions: There is good evidence that COPD is associated with increased risk of $\mathrm{Ml}$; however, it is unclear to what extent this association is due to smoking status. There is some evidence that the risk of $\mathrm{MI}$ is higher during AECOPD than stable periods. There is poor evidence that COPD is associated with increased in hospital mortality after an MI, and good evidence that longer term mortality is higher for patients with COPD after an MI.

\section{INTRODUCTION}

Cardiovascular disease is a common comorbidity and cause of death in people

\section{Strengths and limitations of this study}

- This systematic review investigated three important areas relating to the relationship between chronic obstructive pulmonary disease (COPD) and cardiovascular disease: (1) the risk of myocardial infarction (MI) associated with COPD; (2) the risk of $\mathrm{MI}$ associated with acute exacerbations of COPD; and (3) the risk of death following $\mathrm{MI}$ in patients with COPD compared to patient without COPD.

- Strengths of this review were the wide search strategy, broad inclusion criteria and rigorous risk of bias assessment of included studies.

- We found strong evidence for an increased risk of MI in people with COPD and an increased risk of longer term death after MI for patients with COPD; however, it is unclear how much of this increased risk may be due to smoking status.

- We found poorer evidence for an increased risk of $\mathrm{MI}$ during periods of acute exacerbation of COPD compared to stable periods, and for an increased risk of death in hospital after MI for patients with COPD. We make recommendations on how future studies can improve our understanding of these relationships.

- Due to statistical and clinical heterogeneity, meta-analysis could only be conducted for some of the research questions.

with chronic obstructive pulmonary disease (COPD), with up to one-third dying of cardiovascular disease. ${ }^{1}$ Reducing the cardiovascular disease in this population is an important strategy for reducing the burden of COPD.

Several studies have shown that people with COPD have a higher risk of myocardial infarction (MI) than people without COPD. $^{2-4}$ One of the reasons for the increased risk of MI in patients with COPD is the shared major risk factor of smoking. In addition, several other cardiovascular risk 
factors, including hypertension, diabetes, inactivity, poor diet, and older age, are also prevalent in patients with COPD. ${ }^{5-7}$ In addition, several studies have found an association between reduced $\mathrm{FEV}_{1}$ (forced expiratory volume $1 \mathrm{~s}$ ) and cardiovascular mortality in the general population. ${ }^{8}$ However, COPD itself is also thought to be an independent risk factor for MI with increased risk of MI possibly being mediated through increased systemic inflammation or reduced $\mathrm{FEV}_{1}$ in people with COPD.

Acute exacerbations of COPD are events in the natural history of COPD which are characterised by an increase in COPD symptoms such as breathlessness, cough, sputum volume, and sputum purulence. It has recently been suggested that acute exacerbations of COPD (AECOPD) represent a period of increased risk of MI for people with COPD. ${ }^{9}$ A subtype of patients with COPD appears to have more frequent exacerbations than others. Frequent exacerbators have been defined as individuals who have two or more treated exacerbations per year. Frequent exacerbators may be at higher risk of MI compared to infrequent exacerbators, even during stable periods.

Several investigators have found that patients with COPD have worse mortality in hospital and following discharge after an MI compared to patient without COPD. ${ }^{10-12}$ However, the finding that patients with COPD have greater in hospital and short-term mortality has not been found by all investigators. ${ }^{13-15}$

We aimed to systematically review the literature reporting on: (1) the risk of MI in people with COPD; (2) the risk of MI associated AECOPD, either during AECOPD or that associated with the frequent exacerbator phenotype; and (3) the risk of death after MI in people with COPD. These questions represent the most salient aspects of current research into the relationship between COPD and cardiovascular disease, and no systematic reviews have been published on these topics to date.

\section{METHODS}

\section{Literature search}

MEDLINE, MEDLINE In-Process \& Other Non-Indexed Citations, EMBASE, BIOSIS \& Science Citation Index were searched up to January 2015. A search strategy was devised which would pick up articles relevant to all three research questions. All strategies were based on the MEDLINE search strategy, which is presented in the online supplementary material. In brief, the literature was searched for terms which relate to COPD and terms with relate to MI, and these searches were combined using the AND Boolean logic operator. MeSH terms were combined with natural language searching using truncation where appropriate.

\section{Inclusion and exclusion criteria}

Inclusion and exclusion criteria were applied for each of the three research questions. Studies were included if they met the population, exposure, comparator and outcome criteria. These are presented below for each research question. Studies were included from database start date and were not restricted by language.

\section{Risk of MI in people with COPD}

The population of interest was the general population. The exposure of interest was diagnosis of COPD. The un-exposed group was people without a diagnosis of COPD. The outcome of interest was acute MI.

\section{Risk of MI associated with AECOPD}

The population of interest was people with a diagnosis of COPD. The exposures of interest were either: (1) discrete episodes of AECOPD or periods within 8 weeks of an AECOPD; or (2) frequent exacerbator phenotype. The comparators of interest were either: (1) periods of stable COPD; or (2) infrequent exacerbator phenotype. Studies were included if these reported a relative risk of MI, or if this could be calculated.

\section{Risk of death after MI in people with COPD}

The population of interest was those presenting to a hospital with an MI. Studies were included if these compared patients with a diagnosis of COPD to those without a diagnosis of COPD. Outcomes of interest were death in hospital and at any reported time points post discharge. Studies investigating risk of death for patients with COPD after an interventional procedure following an MI (such as percutaneous coronary intervention or coronary artery bypass graft) were specifically excluded under the population criterion.

\section{Selection of included studies}

Titles and abstracts, where available, were initially screened for potential inclusion by one reviewer. Full text versions of potentially included studies were then obtained and were screened by two reviewers. Authors were contacted if the information provided in articles was not sufficient to assess whether inclusion criteria were satisfied.

\section{Risk of bias assessment}

All included studies, except for those only reported as conference abstracts, were assessed for risk of bias. The risk of bias tool was informed by the Newcastle-Ottawa scale $;^{16}$ however, we did not make use of a summary score as this is not advisable. ${ }^{17}{ }^{18}$ Risk of bias was assessed across the key domains related to selection of participants, comparability of groups, and measurement of outcomes. Several items were included under each domain, and were adapted for different study types. Where reports of studies included more than one analysis (eg, a case control as well as a cohort analysis) the risk of bias for these analyses were conducted separately. Risk of bias assessment was completed by one reviewer and checked by another. 


\section{Evidence synthesis}

Characteristics and findings of studies were tabulated and compared. Data on severity of COPD was extracted as GOLD stage or $\mathrm{FEV}_{1} \%$ predicted, where available. Information was also extracted on smoking status and previous cardiovascular disease. Estimates of effect were extracted or calculated, and are presented as ORs, risk ratios ( $R R$ ), incidence rate ratios (IRR) or HRs.

Where included studies were reasonably statistically and clinically similar, we pooled results using random effects meta-analysis. We used the generic inverse variance method to pool maximally adjusted effect estimates. Analysis was conducted in Review Manager 5.3. Where studies were too statistically $\left(\mathrm{I}^{2}\right.$ over $\left.75 \%\right)$ or clinically heterogeneous, meta-analysis was not conducted, but study summary results were graphed on forest plots without pooling the results. Studies which were not adjusted at all were not included in forest plots. For the question on risk of MI associated with COPD, studies were stratified by adjustment for smoking status (yes or no) and study design (cohort or case-control). For the question on risk of death following MI in COPD compared to patient without COPD, studies were stratified by outcome time point (in-hospital mortality or follow-up mortality). For follow-up mortality, studies were further stratified by analysis.

\section{RESULTS}

\section{Identified studies}

Literature searches yielded 8362 records. After title and abstract screening, 49 records were selected for full-text assessment, which resulted in the inclusion of 24 studies. The inclusion and exclusion process is summarised in figure 1. Of the 24 included studies, 9 investigated the risk of $\mathrm{MI}$ in patients with COPD compared to patient without COPD; 2 investigated the risk of $\mathrm{MI}$ associated

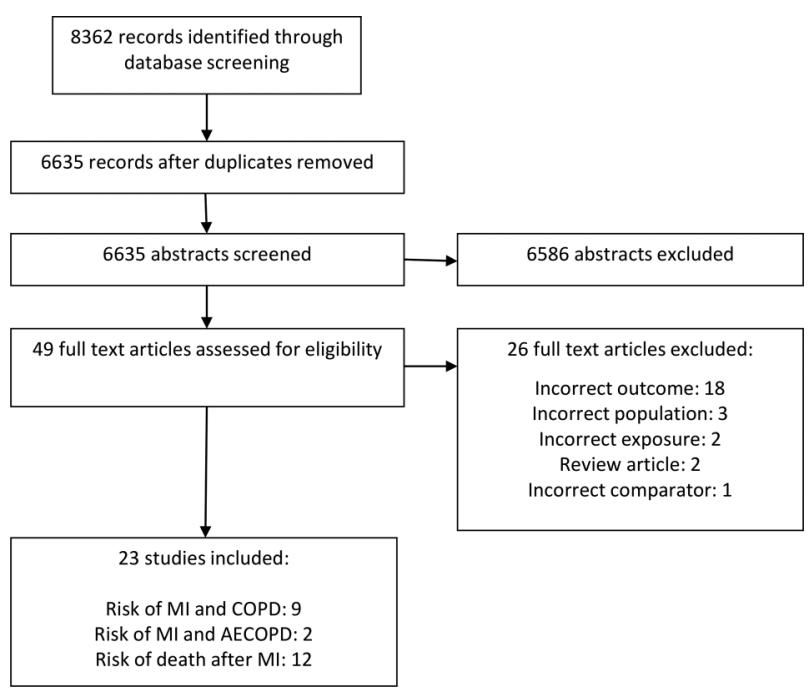

Figure 1 Study selection. AECOPD, acute exacerbation of COPD; COPD, chronic obstructive pulmonary disease; MI, myocardial infarction. with AECOPD; no studies were found which investigated the risk of $\mathrm{MI}$ associated with the frequent exacerbator phenotype; and 12 investigated outcomes after MI for patients with COPD compared to patient without COPD. Summary characteristics of included studies are presented in tables $1-3$.

All of the included studies which investigated risk of MI in people with COPD used data from either routine clinical or administrative databases. COPD was defined using diagnostic codes; these varied between COPD diagnosis in primary care, outpatient departments, hospital admission or discharge codes, and cause of death codes. Three studies also required that patients with COPD had been prescribed COPD medicines. One of the studies, Rodriguez et $a l,{ }^{19}$ included only patients with a recent diagnosis of COPD and followed up to 5 years after this diagnosis to identify MI. Only one study ${ }^{3}$ reported a summary of COPD severity, and only two reported prevalence of current smokers. Four studies reported a cohort analysis only. Two studies ${ }^{4} 19$ reported a cohort analysis as well as a case-control analysis. One study reported the results of a cohort analysis and an analysis of period prevalence. One study ${ }^{20}$ compared rates of $\mathrm{MI}$ in patients with COPD to standardised populations rates of $\mathrm{MI}$.

Two studies ${ }^{9} 21$ were identified which investigated the risk of MI associated with AECOPD. Both studies defined risk periods after the onset of AECOPD and used within person designs to compare the risk to a baseline period.

Nine studies reported mortality for patients with COPD after an MI compared to patient without COPD. Five studies $^{11} 12141522$ reported a comparison of in-hospital mortality after an MI between patients with COPD and patient without COPD. Eight studies ${ }^{10} 12 \quad 13 \quad 23-27$ used a time-to-event analysis to investigate death after discharge from a hospital admission for MI.

\section{Risk of bias assessment}

The proportion of studies (or analyses, where appropriate) which were assessed as having either lower, unclear or higher risk of bias for each of the research questions is presented in figure 2. Detailed results from the risk of bias assessment for individual studies are presented in the appendix.

\section{Risk of MI in people with COPD}

Of nine included studies, eight found a higher risk of MI in patients with COPD compared to patient without COPD. Six studies estimated the ratio of incidence rates of MI in patients with COPD compared to patient without COPD. Five studies 419202829 estimated this for all MIs, this ranged from IRR 1.18 (95\% CI 0.81 to 1.71$)$ to 5.31 (4.54 to 6.21 ). One study ${ }^{2}{ }^{30}$ estimated the IRR for hospitalisation due to MI (IRR 1.49, 95\% CI 0.71 to 3.13) and fatal MIs $(1.51,1.14$ to 2.01$)$. Two studies ${ }^{31} 32$ estimated the ratio of hazard of $\mathrm{MI}$ in patients with COPD compared to patient without COPD one study 


\begin{tabular}{|c|c|c|c|c|c|c|}
\hline Study & $\begin{array}{l}\text { Design and } \\
\text { setting }\end{array}$ & Population & $\begin{array}{l}\text { Characteristics } \\
\text { of COPD patients }\end{array}$ & MI definition & $\begin{array}{l}\text { Maximally adjusted } \\
\text { estimate }(95 \% \mathrm{Cl})\end{array}$ & Factors adjusted for \\
\hline $\begin{array}{l}\text { Curkendall } \\
\text { et } \mathrm{al}^{2} 30\end{array}$ & $\begin{array}{l}\text { Cohort in The } \\
\text { Health Improvement } \\
\text { Network, } \\
\text { 2005-2007 }\end{array}$ & $\begin{array}{l}11493 \text { COPD patients } \\
\geq 40 \text { years, identified by } \\
\text { physician claim or } \\
\text { hospital discharge COPD } \\
\text { code and at least two } \\
\text { prescriptions for COPD } \\
\text { medicines within } 6 \\
\text { months of the index } \\
\text { COPD code. } \\
22986 \text { age and sex } \\
\text { matched non-COPD } \\
\text { patients } \\
29870 \text { COPD patients } \\
>35 \text { years identified by } \\
\text { COPD diagnostic code. } \\
1174240 \text { non-COPD } \\
\text { patients }\end{array}$ & $\begin{array}{l}\text { Age } \\
\text { NR } \\
\text { Sex } \\
\text { NR } \\
\text { COPD severity } \\
\text { NR } \\
\text { Current smokers } \\
16 \% \\
\text { History of CVD } \\
\text { Previous } \\
\text { Ml-2.3\% } \\
\text { Previous } \\
\text { angina-6.6\% } \\
\text { Age } \\
35-44-1.8 \% \\
45-54-7.0 \% \\
55-64-20.5 \% \\
65-74-31.7 \% \\
\geq 75-39.0 \% \\
\text { Sex } \\
48.1 \% \text { male } \\
\text { COPD severity } \\
\text { FEV } \% \text { predicted } \\
50-80 \%-37.5 \% \\
30-49 \%-19.1 \% \\
<30 \%-5.3 \% \\
\text { Current smokers } \\
65.3 \% \\
\text { History of CVD } \\
\text { Prior CVD-28.0\% }\end{array}$ & $\begin{array}{l}\text { Any MI during follow up: } \\
\text { any inpatient or } \\
\text { outpatient diagnosis } \\
\text { of MI } \\
\text { Hospitalisation due to } \\
\text { MI: primary hospital } \\
\text { discharge diagnosis } \\
\text { of MI } \\
\text { Fatal MI: underlying } \\
\text { cause of death which } \\
\text { initiated the sequence of } \\
\text { events that lead to death } \\
\text { recorded as Ml } \\
\text { Diagnostic code for MI } \\
\text { in primary care record }\end{array}$ & $\begin{array}{l}\text { 35-44 years: } \\
\text { HR } 10.34(3.28-32.6) \\
\text { 45-54 years: } \\
\text { HR } 1.22(0.55-2.74) \\
\text { 55-64 years: } \\
\text { HR } 1.55(1.07-2.26) \\
65-74 \text { years: } \\
\text { HR } 1.78(1.37-2.31) \\
\geq 75 \text { years: } \\
1.34(1.03-1.73)\end{array}$ & $\begin{array}{l}\text { Period prevalence of MI: Age, } \\
\text { sex, history of cardiovascular } \\
\text { disease, diabetes, } \\
\text { hypertension, } \\
\text { hypercholesterolaemia } \\
\text { Hospitalisation for MI: adjusted } \\
\text { for history of cardiovascular } \\
\text { events, diabetes, hypertension, } \\
\text { and hypercholesterolemia using } \\
\text { Poisson regression, age and } \\
\text { sex by matching. } \\
\text { Fatal Ml: age and sex by } \\
\text { matching only. } \\
\text { Age, sex and smoking status }\end{array}$ \\
\hline
\end{tabular}




\begin{tabular}{|c|c|c|c|c|c|c|}
\hline Study & $\begin{array}{l}\text { Design and } \\
\text { setting }\end{array}$ & Population & $\begin{array}{l}\text { Characteristics } \\
\text { of COPD patients }\end{array}$ & MI definition & $\begin{array}{l}\text { Maximally adjusted } \\
\text { estimate }(95 \% \mathrm{CI})\end{array}$ & Factors adjusted for \\
\hline Huiart et $a l^{28}$ & $\begin{array}{l}\text { Cohort in the } \\
\text { Saskatchewan } \\
\text { Health databases } \\
\text { 1990-1999 }\end{array}$ & $\begin{array}{l}5648 \text { COPD patients } \\
\geq 50 \text { years, identified by } \\
\text { prescription of three or } \\
\text { more bronchodilators } \\
\text { within the period of one } \\
\text { year. } \\
\text { Rates of MI compared to } \\
\text { those of general } \\
\text { Saskatchewan population }\end{array}$ & $\begin{array}{l}\text { Age } \\
\text { NR } \\
\text { Sex } \\
\text { NR } \\
\text { COPD severity } \\
\text { NR } \\
\text { Current smokers } \\
\text { NR } \\
\text { History of CVD } \\
\text { NR } \\
\text { Characteristics } \\
\text { were not split by } \\
\text { COPD status. }\end{array}$ & $\begin{array}{l}\text { Primary hospital } \\
\text { discharge diagnosis of } \\
\text { MI }\end{array}$ & $\begin{array}{l}\text { Standardised IRR: } 1.30 \\
(1.15-1.44)\end{array}$ & Age and sex by standardisation \\
\hline Mapel et $a l^{28}$ & $\begin{array}{l}\text { Cohort in the } \\
\text { Veterans } \\
\text { Administration } \\
\text { Medical System, } \\
\text { 1991-1999 }\end{array}$ & $\begin{array}{l}\text { COPD patients identified } \\
\text { by discharge codes } \\
\text { (1991-1999) and/or } \\
\text { outpatient codes } \\
\text { (1997-1999) } \\
\text { Age and sex matched } \\
\text { controls without COPD }\end{array}$ & $\begin{array}{l}\text { Age } \\
\text { Median } 60 \text { (IQR, } \\
49-62) \\
\text { Sex } \\
95.7 \% \text { male } \\
\text { COPD severity } \\
\text { NR } \\
\text { Current smokers } \\
\text { NR } \\
\text { History of CVD } \\
\text { Cardiovascular } \\
\text { disease-71.2\% }\end{array}$ & $\begin{array}{l}\text { Specific ICD-9-CM code } \\
\text { for MI during } 1999 \text { that } \\
\text { was not present in } 1998\end{array}$ & $\begin{array}{l}\text { COPD patients identified } \\
\text { using discharge codes } \\
\text { IRR: } 1.28 \text { (1.18-1.38) } \\
\text { COPD patients identified } \\
\text { using outpatient codes } \\
\text { IRR: } 5.31 \text { (4.54-6.21) }\end{array}$ & Age and sex by matching \\
\hline $\begin{array}{l}\text { Rodriguez } \\
\text { et } a l^{19}\end{array}$ & $\begin{array}{l}\text { Cohort and } \\
\text { case-control study } \\
\text { in the General } \\
\text { Practice Research } \\
\text { Database, } \\
\text { 1996-2001 }\end{array}$ & $\begin{array}{l}1532 \text { patients with a first } \\
\text { COPD diagnosis in } 1996, \\
\text { and no history of } \\
\text { cardiovascular disease } \\
13500 \text { age and sex } \\
\text { matched non-COPD } \\
\text { patients, with no history } \\
\text { of cardiovascular disease }\end{array}$ & $\begin{array}{l}\text { Age } \\
\text { NR } \\
\text { Sex } \\
\text { NR } \\
\text { COPD severity } \\
\text { NR } \\
\text { Current smokers } \\
\text { NR } \\
\text { History of CVD } \\
\text { NR }\end{array}$ & $\begin{array}{l}\text { Diagnostic code for MI } \\
\text { in primary care record }\end{array}$ & $\begin{array}{l}\text { Cohort analysis: } \\
\text { IRR } 1.18(0.81-1.71) \\
\text { Case-control analysis: OR } \\
0.93(0.62-1.39)\end{array}$ & $\begin{array}{l}\text { Cohort analysis: } \\
\text { Age and sex } \\
\text { Case control analysis: } \\
\text { Age, sex, smoking and number } \\
\text { of primary care physician visits }\end{array}$ \\
\hline
\end{tabular}




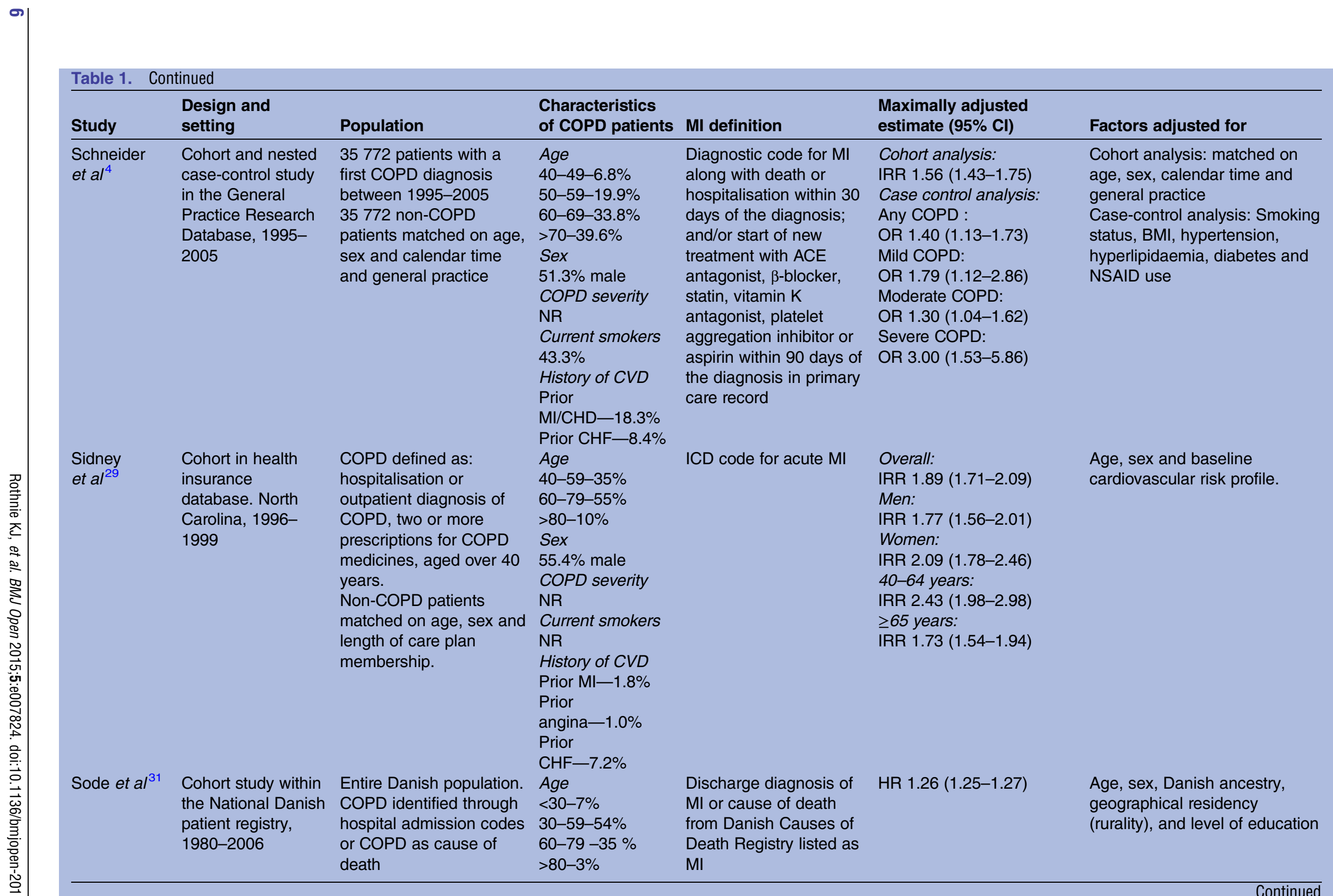

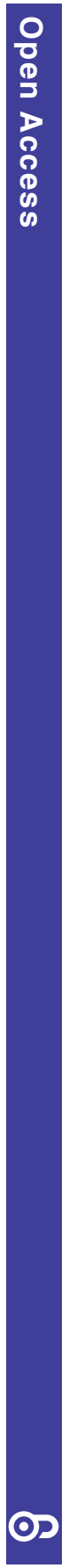

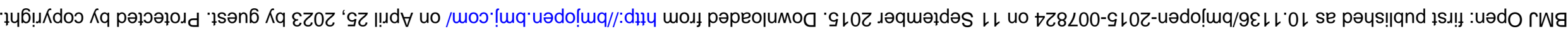




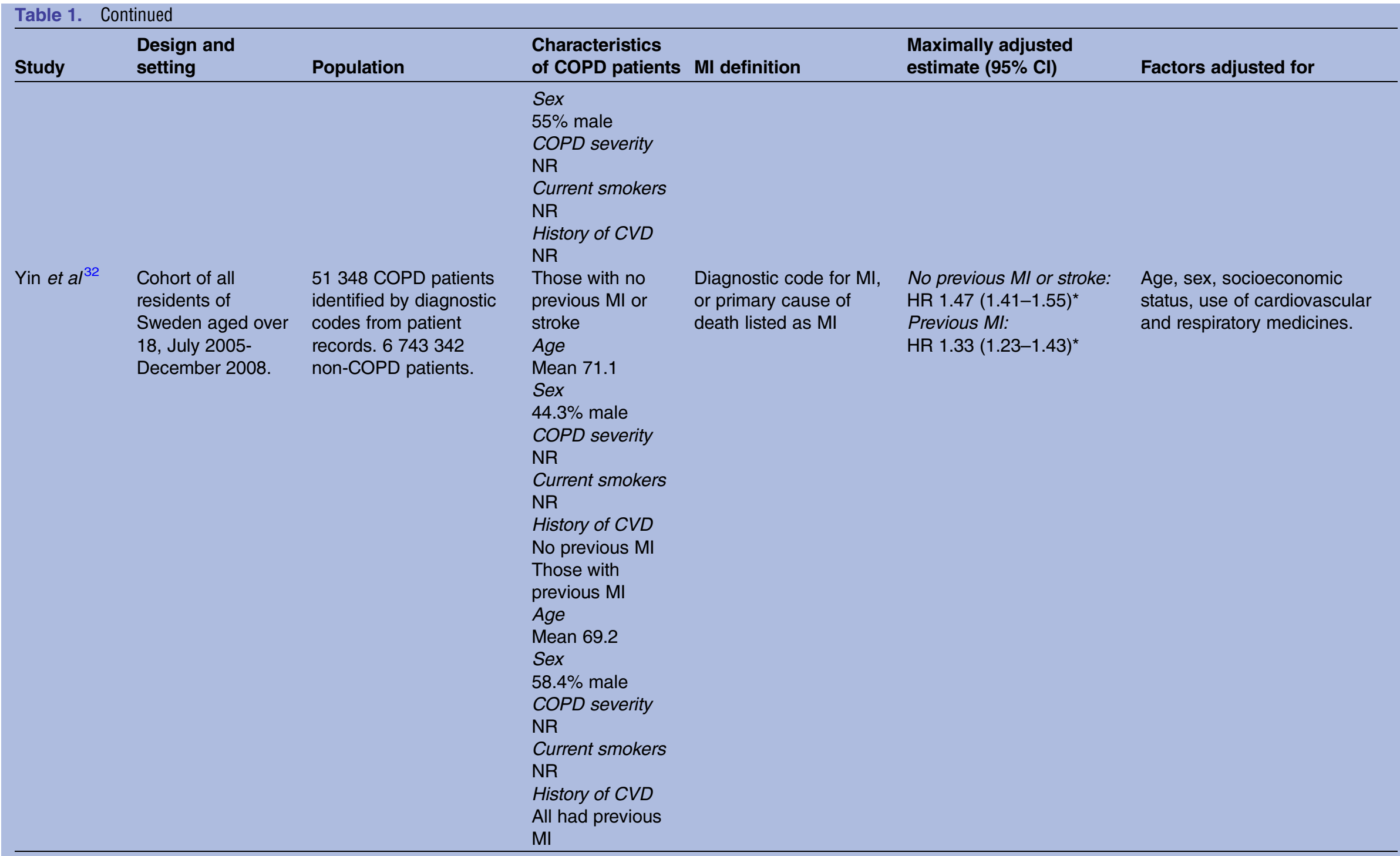

${ }^{*}$ Data from personal communication (Magnus Back. Email communication. 18/08/2014).

COPD, chronic obstructive pulmonary disease; CVD, cardiovascular disease; FEV1, forced expiratory volume in 1 s; ICD, International Classification of Diseases; IRR, incidence rate ratios; $\mathrm{MI}$, myocardial infarction. 


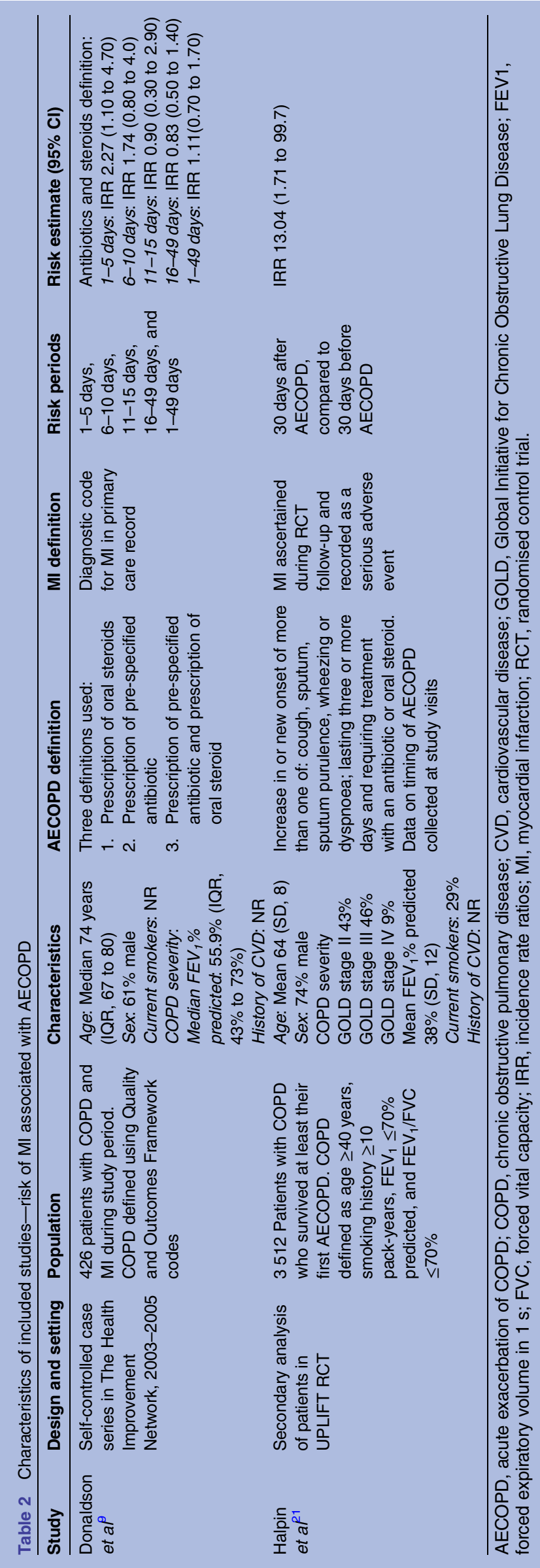

estimated this to be HR $1.2695 \%$, CI 1.25 to 1.27 , while the other study estimated this to be HR 1.47 (1.41 to 1.55) for those with no previous MI, and HR 1.33 (1.23 to 1.43 ) for those with a previous MI. One study ${ }^{2}{ }^{30}$ estimated the ratio of odds of period prevalence over 5 years of acute MI in patients with COPD compared to patient without COPD (OR 1.61, 95\% CI 1.43 to 1.81 ). Only one ${ }^{3}$ of the included cohort studies compared risk of MI in people with COPD and people without COPD adjusted for smoking status. This study reported results stratified by age groups. Meta-analysis of these results showed an increased risk of MI for people with COPD (HR 1.72, 95\% CI 1.22 to 2.42) (figure 3). Two of the included case-control studies adjusted for smoking status. Meta-analysis of these results did not show an increased risk of MI for people with COPD (OR 1.18, $95 \%$ CI 0.80 to 1.76 ) (figure 4). Meta-analysis was not conducted for the studies which did not adjust for smoking as heterogeneity was too high $\left(\mathrm{I}^{2}=93 \%\right)$. These results are graphically summarised in figure 5 .

Some studies investigated whether the effect of COPD on the risk of MI was different in terms of age and severity of airflow obstruction. Feary $e t a \vec{l}$ found that the effect of COPD on risk of MI was higher in the 35-44 year age group (HR 10.34, 95\% CI 3.28 to 32.6) compared to older age groups (45-54 years: HR 1.22 (95\% CI 0.55-2.74), 55-64 years: HR 1.55 (95\% CI 1.07 to 2.26), 65-74 years: HR 1.78 (95\% CI 1.37 to 2.31), $\geq 75$ years: HR 1.34 (95\% CI 1.03 to 1.73$)$ ). Sidney $2005^{29}$ reported similar findings; the effect of COPD on risk of MI was higher in those who were aged 40-64 years (HR 2.43, 95\% CI 1.98 to 2.98) compared to those who were aged over 64 years (HR 1.73, 95\% CI 1.54 to 1.94$)$. Schneider $e t a l^{4}$ investigated the risk of MI by sub-group of COPD severity. They found that the effect of COPD on the risk of MI was greater in those with severe COPD (OR 3.00, 95\% CI 1.53 to 5.86) compared to those with moderate COPD (OR 1.30, 95\% CI 1.04 to 1.62 ) or mild COPD (OR $1.79,95 \%$ CI 1.12 to 2.86$)$.

\section{Risk of MI associated with AECOPD}

Donaldson $2010^{9}$ conducted a self-controlled case series using data from The Health Improvement Network (THIN). They used prescription of antibiotics and steroids in patient with COPD to identify AECOPD, and report an increased risk of MI in the 1-5 days following the onset of AECOPD (IRR 2.27, 95\% CI 1.10 to 4.70 ). No difference in the risk of MI was found for the period 6-49 days, or at any time point when the alternative definitions of AECOPD of prescription of steroids alone or antibiotics alone were used. Halpin $e t a l^{21}$ reported a secondary analysis of the UPLIFT trial, which was an RCT comparing inhaled tiotropium and placebo in patients with COPD with a primary outcome of reduction in $\mathrm{FEV}_{1}$ decline. Time to first AECOPD was a secondary outcome. AECOPD were identified using a symptombased definition and were reported to trial staff at 
Table 3. Characteristics of included studies - risk of death after MI

\begin{tabular}{|c|c|c|c|c|c|}
\hline Study & Design and setting & Population & $\begin{array}{l}\text { COPD patient } \\
\text { characteristics }\end{array}$ & $\begin{array}{l}\text { Maximally adjusted } \\
\text { estimate for mortality } \\
\text { (95\% CI) }\end{array}$ & Factors adjusted for \\
\hline $\begin{array}{l}\text { Andell } \\
\text { et } a l^{10}\end{array}$ & $\begin{array}{l}\text { Cohort study within the } \\
\text { Swedish SWEDEHEART } \\
\text { registry between 2005-2010. }\end{array}$ & $\begin{array}{l}\text { Consecutive patients admitted to } \\
\text { Swedish coronary care units. COPD } \\
\text { diagnosis ascertained through } \\
\text { linkage to the Swedish National } \\
\text { Patient Registry. }\end{array}$ & $\begin{array}{l}\text { Age } \\
\text { Mean } 75 \text { years } \\
\text { (SD, } 9) \\
\text { Sex } \\
54 \% \text { male } \\
\text { COPD severity } \\
\text { NR } \\
\text { Current smokers } \\
32.9 \% \\
\text { History of CVD } \\
\text { Prior Ml } 13.7 \% \\
\text { Prior HF } 20.2 \%\end{array}$ & $\begin{array}{l}\text { Mortality at one year: } \\
\text { HR } 1.14 \text { (1.07-1.21) }\end{array}$ & $\begin{array}{l}\text { Age, sex, smoking, comorbidity } \\
\text { (previous Ml, previous stroke, heart } \\
\text { failure, renal failure, hypertension, } \\
\text { diabetes, peripheral artery disease, } \\
\text { cancer and previous bleeding), in } \\
\text { hospital treatment and discharge } \\
\text { medications (heparin, } \\
\text { fondaparinux, dalteparin, } \\
\text { enoxaparin, glycoprotein Ilb/lla } \\
\text { inhibitors, angioplasty, coronary } \\
\text { stenting, } \beta \text {-blockers, aspirin, } \\
\text { clopidogrel, prasugrel, calcium } \\
\text { channel blockers, digoxin, } \\
\text { diuretics, statins, nitrates and } \\
\text { warfarin). }\end{array}$ \\
\hline $\begin{array}{l}\text { Behar } \\
\text { et } a l^{22}\end{array}$ & $\begin{array}{l}\text { Cohort study in Israel between } \\
1981-1983\end{array}$ & $\begin{array}{l}2276 \text { consecutive patients surviving } \\
\text { an Ml after admission to } 13 \\
\text { coronary care units. Patients with a } \\
\text { history of chronic bronchitis or } \\
\text { chronic airways obstruction and } \\
\text { clinical and/or radiographic findings } \\
\text { compatible with COPD during } \\
\text { hospitalisation for Ml were included. }\end{array}$ & $\begin{array}{l}\text { Age } \\
\text { Mean } 66.8 \text { years } \\
\text { (SD, 9.7) } \\
\text { Sex } \\
79.3 \% \text { male } \\
\text { COPD severity } \\
\text { NR } \\
\text { Current smokers } \\
43.3 \% \\
\text { History of CVD } \\
\text { Prior Ml—28.8\% } \\
\text { Prior angina- } 55.4 \%\end{array}$ & $\begin{array}{l}\text { Unadjusted:* }^{*} \\
\text { In -hospital RR } 1.39 \\
\text { (1.16-1.67) } \\
1 \text { year RR } 1.34 \\
\text { (1.16-1.55) } \\
5 \text { years RR } 1.28 \\
(1.18-1.40)\end{array}$ & \\
\hline Bursi et $a l^{23}$ & $\begin{array}{l}\text { Cohort study of the population } \\
\text { in the Rochester Epidemiology } \\
\text { project involving residents in } \\
\text { Olmsted County, Minnesota } \\
\text { from } 1979 \text { to } 2007\end{array}$ & $\begin{array}{l}\text { Local residents in Olmsted County. } \\
\text { MI ascertained from medical } \\
\text { records compatible with ICD } \\
\text { criteria. Information on COPD was } \\
\text { also obtained from ICD codes. }\end{array}$ & $\begin{array}{l}\text { Age } \\
\text { Mean } 73 \text { years } \\
\text { (SD, } 11) \\
\text { Sex } \\
59 \% \text { male } \\
\text { COPD severity } \\
\text { NR } \\
\text { Current smokers } \\
35 \% \\
\text { History of CVD } \\
\text { Those with prior CVD } \\
\text { excluded }\end{array}$ & $\begin{array}{l}\text { HR } 1.30 \text { ( } 1.10 \text { to } 1.54) \text {, } \\
\text { mean follow up } 4.7 \text { years. }\end{array}$ & $\begin{array}{l}\text { Age, sex, smoking, hypertension, } \\
\text { MI type (STEMI/non-STEMI), } \\
\text { creatine kinase level, } \\
\text { killip class, reperfusion treatment in } \\
\text { hospital, use of drugs on discharge } \\
\text { ( } \beta \text {-blockers, ACEi, diuretics) }\end{array}$ \\
\hline
\end{tabular}


Enriquez Cross sectional study of et al ${ }^{11}$ National Cardiovascular Data Registry in the USA between January 2008 and December 2010

Cohort study within Krakow Registry of ACS in February 2005-March 2005 and

December 2005-January 2006

and

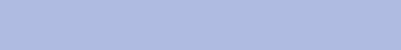

\section{Population}

1414 patients with Ml admitted to hospital in Krakow, Poland. Those with a previous history of COPD

and current treatment with a steroid or bronchodilator were classified as COPD patients.

158890 patients admitted to one of Age 445 sites with an MI. COPD patients had a history of COPD or were using long term inhaled or oral $\beta$-agonists, inhaled anti-inflammatory agents, leukotriene receptor antagonists or inhaled steroids.
COPD patient

characteristics

Age

Mean 71.8 years (SD, 11)

Sex

$62 \%$ male COPD severity NR

Current smokers $40.7 \%$

History of CVD

MI 34.6\%

Angina $80.2 \%$

HF $30.9 \%$

EMI-median

66 years

70 years

Sex

STEMI-60.4\% male

nSTEMI-57.5\%

male

COPD severity

NR

Current smokers

STEMI-57.0\%

nSTEMI-41.9\%

History of CVD

STEMI

Prior $\mathrm{Ml}-29.7 \%$

Prior CHF-15.3\%

nSTEMI

Prior $\mathrm{Ml}-39 . \%$

Prior $\mathrm{CHF}-33.3 \%$
Maximally adjusted

estimate for mortality

(95\% Cl)

Factors adjusted for

HR 2.15 (1.30-3.55)

Age, sex, BMI, diabetes,

hypertension, hyperlipidaemia, prior angina, prior MI, prior heart

failure, left ventricular ejection

fraction, prior $\mathrm{PCI}$, prior $\mathrm{CABG}$,

prior stroke or transient ischaemic

attack, smoking status, peripheral

arterial disease, chronic renal

insufficiency, parameters on

admission (chest pain,

cardiogenic shock, heart rate,

systolic blood pressure, diastolic

blood pressure), time from chest

pain onset to admission and type of $\mathrm{MI}$ (STEMI or NSTEMI)

In-hospital mortality

Age, serum creatinine, systolic

STEMI OR 1.05

(0.95-1.17)

Non-STEMI OR 1.21

(1.11-1.33)

blood pressure, troponin elevation,

heart failure or cardiogenic shock

at presentation, ST-segment

changes, heart rate and prior

peripheral arterial disease. 


\begin{tabular}{|c|c|c|c|c|c|}
\hline Study & Design and setting & Population & $\begin{array}{l}\text { COPD patient } \\
\text { characteristics }\end{array}$ & $\begin{array}{l}\text { Maximally adjusted } \\
\text { estimate for mortality } \\
(95 \% \mathrm{Cl})\end{array}$ & Factors adjusted for \\
\hline Hadi et al ${ }^{15}$ & $\begin{array}{l}\text { Cross sectional study of } \\
\text { patients hospitalised with ACS } \\
\text { in May } 2006 \text { and January } \\
2007 \text { to June } 2007 \text { in six } \\
\text { Middle Eastern countries }\end{array}$ & $\begin{array}{l}8169 \text { consecutive patients in the } \\
\text { Gulf RACE registry presenting with } \\
\text { ACS at } 65 \text { centres across six } \\
\text { countries. COPD patients were } \\
\text { identified from 1) medical records or } \\
\text { 2) use of COPD medicines. }\end{array}$ & $\begin{array}{l}\text { Age } \\
\text { Median } 64 \\
\text { (IQR, 56-71) } \\
\text { Sex } \\
\text { NR } \\
\text { COPD severity } \\
\text { NR } \\
\text { Current smokers } \\
38.7 \% \\
\text { History of CVD } \\
\text { Prior MI-34.8\% } \\
\text { Prior angina }-54.4 \%\end{array}$ & $\begin{array}{l}\text { In hospital mortality: } \\
\text { OR } 0.40(0.20-1.24)\end{array}$ & $\begin{array}{l}\text { Age, sex, cardiogenic shock, use } \\
\text { of thrombolysis, use of aspirin, use } \\
\text { of } \beta \text {-blocker, use of ACEi }\end{array}$ \\
\hline $\begin{array}{l}\text { Hawkins } \\
\text { et }\left.a\right|^{25}\end{array}$ & $\begin{array}{l}\text { Cohort study of patients with } \\
\text { acute Ml enrolled in VALIANT } \\
\text { trial }\end{array}$ & $\begin{array}{l}\text { Patients with MI complicated by } \\
\text { LVSD and HF. COPD was identified } \\
\text { by a questionnaire completed by } \\
\text { trial site investigators. }\end{array}$ & $\begin{array}{l}\text { Age } \\
\text { Mean } 68.1 \text { (SD, 9.9) } \\
\text { Sex } \\
71.1 \% \text { male } \\
\text { COPD severity } \\
\text { NR } \\
\text { Current smokers } \\
42.0 \% \\
\text { History of CVD } \\
\text { Prior Ml-39.9\% } \\
\text { Prior angina-46.1\% } \\
\text { Prior HF- } 27.3 \%\end{array}$ & HR 1.14 (1.02-1.28) & $\begin{array}{l}\text { Age, heart rate, systolic and } \\
\text { diastolic blood pressure, weight, } \\
\text { baseline creatinine, smoking } \\
\text { status, diabetes, dyslipidaemia, } \\
\text { hypertension, killip classification, } \\
\text { anterior Ml, new lower bundle } \\
\text { branch block, thrombolytic therapy, } \\
\text { primary PCl, coronary artery } \\
\text { bypass graft, history of heart } \\
\text { failure, atrial fibrillation, previous } \\
\text { MI, angina, previous stroke, } \\
\text { peripheral arterial disease, renal } \\
\text { insufficiency, alcohol abuse, } \\
\text { country of enrolment, beta blocker } \\
\text { use, randomised treatment }\end{array}$ \\
\hline $\begin{array}{l}\text { Kjoller } \\
\text { et } a l^{13}\end{array}$ & $\begin{array}{l}\text { Cohort study of consecutive } \\
\text { patients recruited 1-6 days } \\
\text { after an MI }\end{array}$ & $\begin{array}{l}\text { Danish hospitals between May } \\
1990 \text { and July } 1992 \text { as part of } \\
\text { TRACE study. COPD was identified } \\
\text { using either 1) medical records or } \\
\text { 2) patient report in addition to use } \\
\text { of COPD medicines }\end{array}$ & $\begin{array}{l}\text { Age } \\
\text { Median } 70.5 \\
\text { (5-95 percentiles, } \\
50.7-83.5) \\
\text { Sex } \\
68.2 \% \text { men } \\
\text { COPD severity } \\
\text { NR } \\
\text { Current smokers } \\
60.0 \% \\
\text { History of CVD } \\
\text { Previous Ml-25.1\% }\end{array}$ & $\begin{array}{l}\text { Cohort entry to } 30 \text { days: } \\
\text { HR } 0.89 \text { (0.68-1.11) } \\
\text { Cohort entry to } 7 \text { years: } \\
\text { HR } 1.15 \text { (1.04-1.28) }\end{array}$ & $\begin{array}{l}\text { Age, sex, BMI, hypertension, } \\
\text { diabetes, smoking status, previous } \\
\text { angina, wall motion index, angina, } \\
\text { history of CHF, new CHF, atrial } \\
\text { fibrillation, bundle branch block, } \\
\text { wall motion index, use of } \\
\text { thrombolytic therapy }\end{array}$ \\
\hline
\end{tabular}




\begin{tabular}{|c|c|c|c|c|c|}
\hline Study & Design and setting & Population & $\begin{array}{l}\text { COPD patient } \\
\text { characteristics }\end{array}$ & $\begin{array}{l}\text { Maximally adjusted } \\
\text { estimate for mortality } \\
(95 \% \mathrm{Cl})\end{array}$ & Factors adjusted for \\
\hline & & & $\begin{array}{l}\text { Previous } \\
\text { angina-43.9 } \\
\text { Previous } \\
\text { CHF-28.2\% }\end{array}$ & & \\
\hline $\begin{array}{l}\text { Quint et } a l^{26} \\
\text { (abstract) }\end{array}$ & $\begin{array}{l}\text { Cohort study of patients } \\
\text { admitted after a first MI using } \\
\text { data from the UK CALIBER } \\
\text { database }\end{array}$ & $\begin{array}{l}8065 \text { patients admitted to UK } \\
\text { hospitals with a first MI between } \\
\text { Jan 2003-Dec 2008. COPD was } \\
\text { identified using primary care } \\
\text { records. }\end{array}$ & $\begin{array}{l}\text { Age } \\
\text { NR } \\
\text { Sex } \\
\text { NR } \\
\text { COPD severity } \\
\text { NR } \\
\text { Current smokers } \\
\text { NR } \\
\text { History of CVD } \\
\text { NR }\end{array}$ & $\begin{array}{l}\text { Mortality up to } 7 \text { years: } \\
\text { HR } 1.37 \text { (1.23-1.52) }\end{array}$ & Age and sex \\
\hline $\begin{array}{l}\text { Raposeiras } \\
\text { et } \mathrm{al}^{12} \\
\text { (abstract) }\end{array}$ & $\begin{array}{l}\text { Cross sectional and cohort } \\
\text { study of patients with ACS }\end{array}$ & $\begin{array}{l}4497 \text { consecutive patients admitted } \\
\text { to Spanish hospitals for ACS. The } \\
\text { ascertainment method for COPD } \\
\text { was unclear. }\end{array}$ & $\begin{array}{l}\text { Age } \\
\text { NR } \\
\text { Sex } \\
\text { NR } \\
\text { COPD severity } \\
\text { NR } \\
\text { Current smokers } \\
\text { NR } \\
\text { History of CVD } \\
\text { NR }\end{array}$ & $\begin{array}{l}\text { In-hospital death } \\
\text { OR } 1.04 \text { (1.03-1.04) } \\
\text { Follow up mortality } \\
\text { HR } 1.69 \text { (1.41-2.03), } \\
\text { median follow up } 3.1 \\
\text { years }\end{array}$ & $\begin{array}{l}\text { GRACE score } \\
\beta \text {-blocker therapy }\end{array}$ \\
\hline $\begin{array}{l}\text { Rha et } a l^{33} \\
\text { (abstract) }\end{array}$ & $\begin{array}{l}\text { Case control study in Korea } \\
\text { AMI registry from } 2005 \text { to } \\
2007\end{array}$ & AMI patients in KAMIR & $\begin{array}{l}\text { Age } \\
\text { Mean } 71.7 \text { (SD 10.0) } \\
\text { Sex } \\
\text { NR } \\
\text { COPD severity } \\
\text { NR } \\
\text { Current smokers } \\
\text { NR } \\
\text { History of CVD } \\
\text { NR }\end{array}$ & $\begin{array}{l}\text { Mortality at } 8 \text { months } \\
\text { OR } 2.69,95 \% \mathrm{Cl} \text { could } \\
\text { not be calculated from } \\
\text { reported information. }\end{array}$ & Unadjusted \\
\hline $\begin{array}{l}\text { Salisbury } \\
\text { et } a^{27}\end{array}$ & $\begin{array}{l}19 \text { centre prospective study of } \\
\text { patients presenting with } \mathrm{MI} \text { in } \\
\text { a cohort study }\end{array}$ & $\begin{array}{l}\text { MI patients in PREMIER study } \\
\text { restricted to patients discharged } \\
\text { alive after MI. Patients were } \\
\text { considered to have COPD if they } \\
\text { had a documented history of }\end{array}$ & $\begin{array}{l}\text { Age } \\
\text { Mean } 64.5(\mathrm{SD}, 12.4) \\
\text { Sex } \\
61.8 \% \text { male } \\
\text { COPD severity }\end{array}$ & $\begin{array}{l}\text { Mortality up to } 1 \text { year } \\
\text { HR } 2.00 \text { (1.44-2.79) }\end{array}$ & $\begin{array}{l}\text { Age, gender, race, avoidance of } \\
\text { health care due to cost, smoking, } \\
\text { diabetes, hypertension, CHF, } \\
\text { ejection fraction, previous CVD, MI } \\
\text { diagnosis type, new onset HF after }\end{array}$ \\
\hline
\end{tabular}


Table 3. Continued

\begin{tabular}{|c|c|c|c|c|c|}
\hline Study & Design and setting & Population & $\begin{array}{l}\text { COPD patient } \\
\text { characteristics }\end{array}$ & $\begin{array}{l}\text { Maximally adjusted } \\
\text { estimate for mortality } \\
(95 \% \mathrm{Cl})\end{array}$ & Factors adjusted for \\
\hline & & $\begin{array}{l}\text { obstructive pulmonary disease } \\
\text { (COPD or asthma) or had therapy } \\
\text { specific for obstructive pulmonary } \\
\text { disease. }\end{array}$ & $\begin{array}{l}\text { NR } \\
\text { Current smokers } \\
37.6 \% \\
\text { History of CVD } \\
\text { Previous Ml-29.7\% } \\
\text { Previous HF-24.3\% }\end{array}$ & & $\begin{array}{l}\text { Ml, diseased vessels on } \\
\text { angiogram, enrolling site, } \\
\text { percentage of Ml quality of care } \\
\text { indicators of the centre, treatment } \\
\text { type }\end{array}$ \\
\hline $\begin{array}{l}\text { Stefan } \\
\text { et } a l^{14}\end{array}$ & $\begin{array}{l}\text { Cross sectional study with } \\
\text { follow up of patients } \\
\text { hospitalised with AMI at } \\
\text { greater Worcester, } \\
\text { Massachusetts between } \\
\text { 1997-2007 }\end{array}$ & $\begin{array}{l}\text { Patients hospitalised with AMI in } \\
\text { greater Worcester, Massachusetts } \\
\text { medical centres. COPD patients } \\
\text { were identified by previous mention } \\
\text { of clinical or radiographic evidence } \\
\text { for COPD in their medical record. }\end{array}$ & $\begin{array}{l}\text { Age } \\
\text { Mean } 74 \text { years } \\
\text { Sex } \\
52.4 \% \text { male } \\
\text { COPD severity } \\
\text { NR } \\
\text { Current smokers } \\
27.3 \% \\
\text { History of CVD } \\
\text { Prior angina- } 22.3 \% \\
\text { Prior HF- } 38.6 \%\end{array}$ & $\begin{array}{l}\text { In hospital: OR } 1.25 \\
\text { (0.97-1.34) } \\
30 \text { day mortality. OR } 1.31 \\
(1.10-1.58)\end{array}$ & $\begin{array}{l}\text { Age, sex, year of hospitalisation, } \\
\text { history of CVD, history of renal } \\
\text { failure, type of MI (STEMI/ } \\
\text { non-STEMI), length of stay, } \\
\text { smoking status used in secondary } \\
\text { analysis }\end{array}$ \\
\hline
\end{tabular}

${ }^{*}$ Calculated from reported data.

AMI, acute myocardial infarction; BMI, body mass index; CABG, coronary artery bypass grafting; COPD, chronic obstructive pulmonary disease; CVD, cardiovascular disease; HF, heart failure;

LVSD, left ventricular systolic dysfunction; MeSH, Medical Subject Headings; MI, myocardial infarction; NR, not reported; PCI, percutaneous coronary intervention; NSTEMI, non-ST-segment

elevation myocardial infarction; STEMI, ST-segment elevation myocardial infarction. 
A

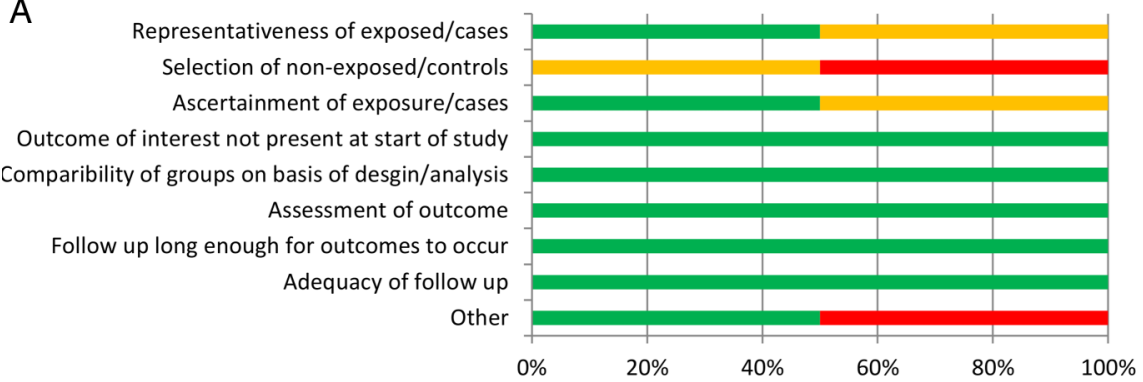

B Representativeness of exposed/cases Selection of non-exposed/controls Ascertainment of exposure/cases Outcome of interest not present at start of study Comparibility of groups on basis of desgin/analysis Assessment of outcome Follow up long enough for outcomes to occur Adequacy of follow up Other

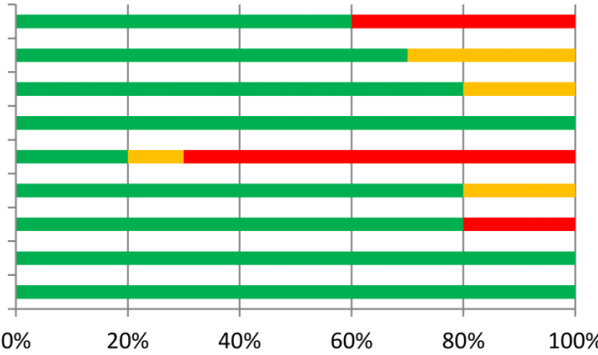

\% Lower risk of bias \% Unclear risk of bias \% Higher risk of bias

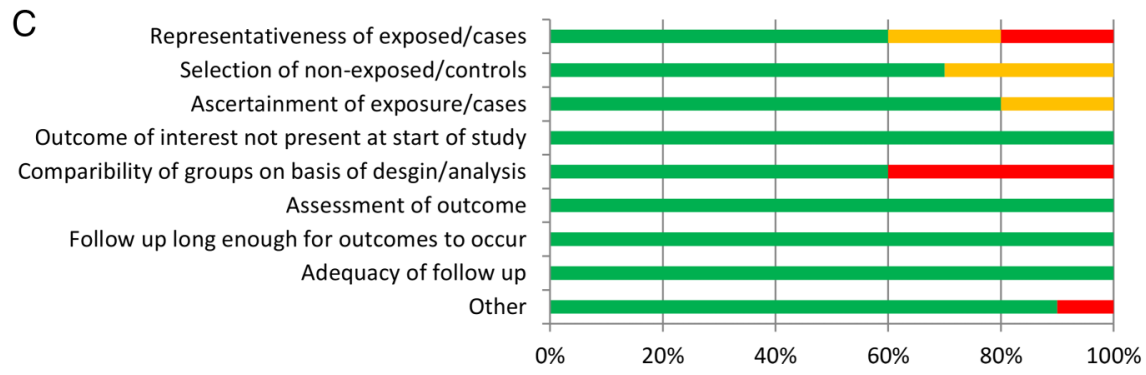

Figure 2 Summary of risk of bias for risk assessments for: A studies investigating risk of MI associated with COPD; B studies investigating risk of $\mathrm{Ml}$ associated with AECOPD; and $\mathrm{C}$ studies investigating risk of death following MI in people with COPD. AECOPD, acute exacerbation of COPD; COPD, chronic obstructive pulmonary disease; MI, myocardial infarction.

regular study visits. Data on MI were collected as serious adverse events. This study found that compared to the 30 days prior to AECOPD, risk of MI in the 30 days following AECOPD was increased (IRR 13.04; 95\% CI 1.71 to 99.7$)$. These results are graphically summarised in figure 6. Owing to different exposure time periods, the results for within person studies investigating the risk of MI associated with AECOPD were not pooled in meta-analysis.
Risk of death after MI in people with COPD

Of the studies investigating differences in in-hospital mortality after an MI, two ${ }^{12} 22$ found an increased risk of mortality for patients with COPD (RR 1.39, 95\% CI 1.16 to 1.67 (unadjusted); and OR $1.04,95 \%$ CI 1.03 to 1.04). Two studies ${ }^{14} 15$ did not find evidence for increased in-hospital mortality for patients with COPD (OR $0.40,95 \%$ CI 0.20 to 1.24 ; OR 1.25 , $95 \%$ CI 0.97 to 1.34). One study ${ }^{11}$ reported results split by type of MI: it

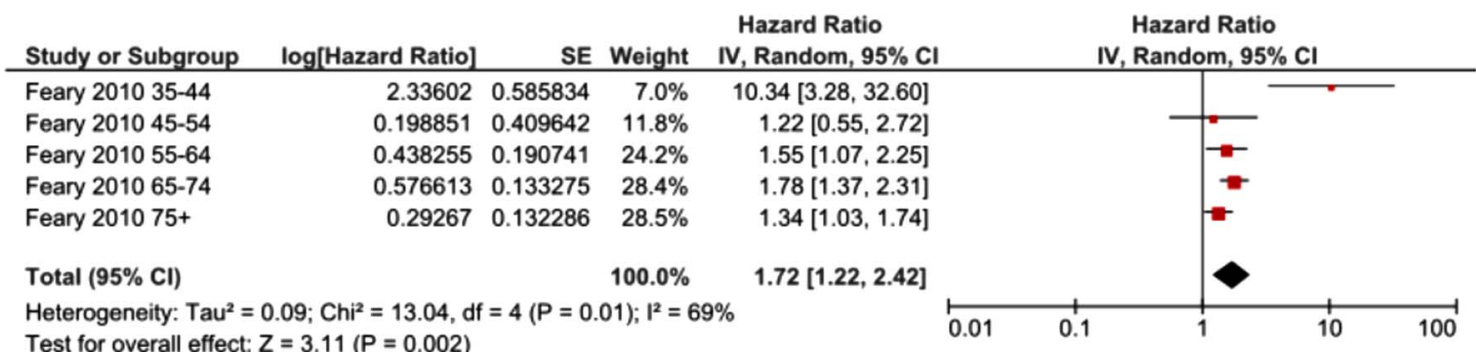

Figure 3 Forest plot showing risk of Ml associated with COPD in cohort studies which adjusted for smoking status. Cls may vary slightly from those quoted in tables due to transformation during meta-analysis. COPD, chronic obstructive pulmonary disease; MI, myocardial infarction. 


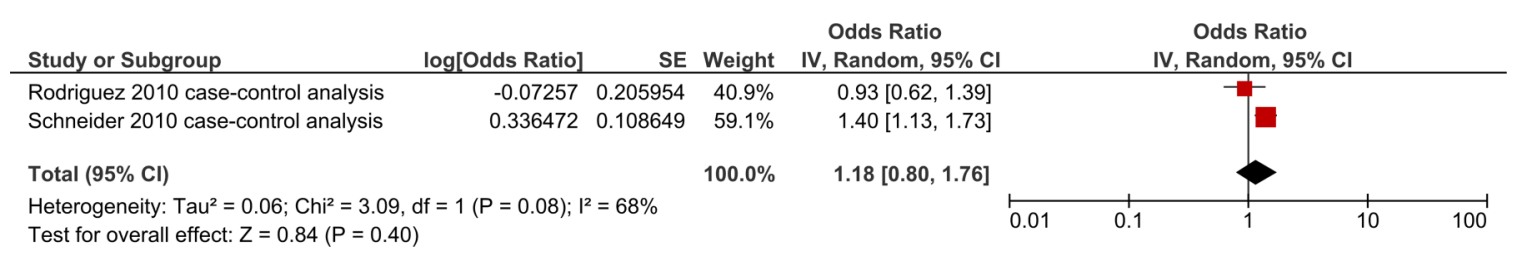

Figure 4 Forest plot showing risk of MI associated with COPD in case-control studies which are adjusted for smoking status. Cls may vary slightly from those quoted in tables due to transformation during meta-analysis. COPD, chronic obstructive pulmonary disease; MI, myocardial infarction.

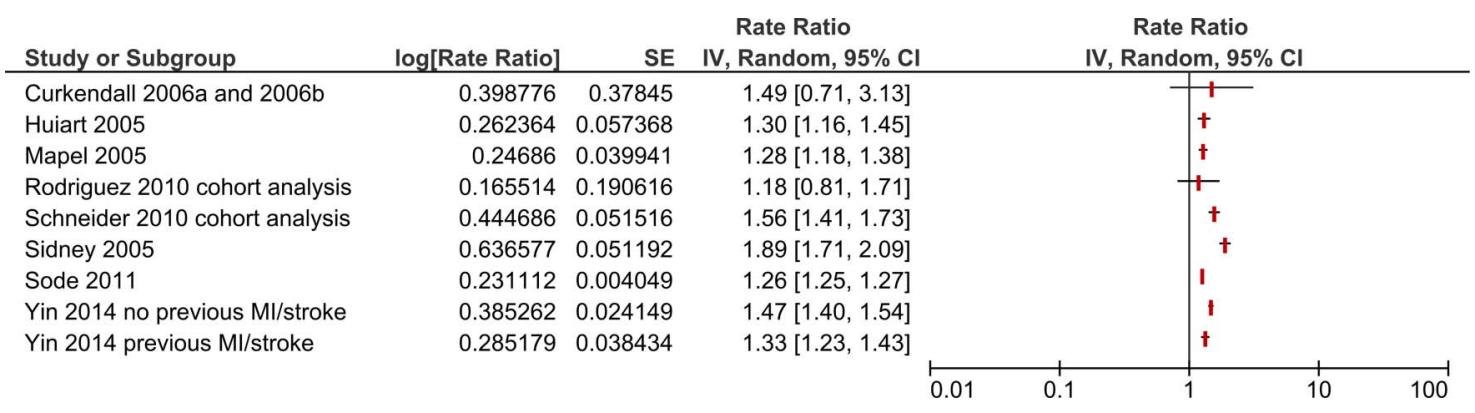

Figure 5 Forest plot showing risk of MI associated with COPD in cohort studies which did not adjust for smoking status. Cls may vary slightly from those quoted in tables due to transformation during meta-analysis. COPD, chronic obstructive pulmonary disease; MI, myocardial infarction.

did not find an increased in-hospital mortality for patients with COPD after a STEMI (OR 1.05, 95\% CI 0.95 to 1.17 ), but did find increased in-hospital death for patients with COPD after a non-STEMI (OR 1.21, $95 \%$ CI 1.11 to 1.33$)$. Meta-analysis of adjusted results showed weak evidence for an increased risk of in-hospital death for patients with COPD (OR 1.13, 95\% CI 0.97 to 1.31 ) (figure 7 ).

One study ${ }^{14}$ reported mortality at 30 days for patients with COPD compared to patient without COPD. This study found increased mortality for patients with COPD (OR $1.31,1.10$ to 1.58$)$. Another study ${ }^{33}$ reported mortality at 8 months, and in an unadjusted analysis, found increased mortality for patients with COPD compared to patients without COPD (OR 2.69, 95\% CI was not reported and could not be calculated). One study ${ }^{22}$ also found, on unadjusted analysis, that mortality was greater for patients with COPD at 1 year (RR 1.34, 95\% CI 1.16 to 1.55 ) and 5 years (RR $1.28,95 \%$ CI 1.18 to 1.40 ) after MI.

Eight studies ${ }^{10} \quad 12 \quad 13 \quad 23-27$ reported results of survival analysis of mortality during follow-up after an MI. All of the studies reported higher mortality for patients with COPD compared to patients without COPD during follow-up after discharge following an MI. HRs ranged from 1.15 (95\% CI 1.04 to 1.28$)$ to 2.15 (95\% CI 1.30 to $3.55)$. However, one of these studies ${ }^{13}$ found no evidence of a difference in mortality when restricting the time period to the first 30 days following discharge (HR $0.89,95 \%$ CI 0.68 to 1.11$)$. Meta-analysis of studies which reported adjusted results showed an increased risk of death after discharge following MI for patients with COPD compared to patients without COPD (HR $1.26,1.13$ to 1.40 ) (figure 8 ). Four of the studies included under this question were excluded from meta-analysis for methodological ${ }^{12} 33$ or clinical heterogeneity. $^{25} 27$

\section{DISCUSSION}

\section{Main findings}

Most studies which investigated the risk of MI in people with COPD found that those with COPD have higher risk of MI than people who do not have COPD; however,

\begin{tabular}{|c|c|c|c|c|c|c|}
\hline Study or Subgroup & log[Rate Ratio] & SE & $\begin{array}{c}\text { Rate Ratio } \\
\text { IV, Random, } 95 \% \mathrm{Cl}\end{array}$ & $\begin{array}{r}\text { Rate } \\
\text { IV, Rando }\end{array}$ & $\begin{array}{l}\text { Ratio } \\
\mathrm{m}, 95 \% \mathrm{Cl}\end{array}$ & \\
\hline Donaldson $20101-5$ days & 0.81978 & 0.370473 & $2.27[1.10,4.69]$ & & 1 & \\
\hline Donaldson 2010 6-10 days & -0.69315 & 0.262658 & $0.50[0.30,0.84]$ & 十 & & \\
\hline Donaldson $201011-15$ days & 0.553885 & 0.410571 & $1.74[0.78,3.89]$ & & & \\
\hline Donaldson $201016-49$ days & -0.10536 & 0.578746 & $0.90[0.29,2.80]$ & & & \\
\hline \multirow[t]{2}{*}{ Halpin 2011 1-30 days } & 2.568022 & 1.037161 & $13.04[1.71,99.57]$ & & & \\
\hline & & & 0.01 & 0.1 & 10 & 100 \\
\hline
\end{tabular}

Figure 6 Forest plot showing risk of MI associated with acute exacerbations of COPD. Cls may vary slightly from those quoted in tables due to transformation during meta-analysis. COPD, chronic obstructive pulmonary disease; MI, myocardial infarction. 


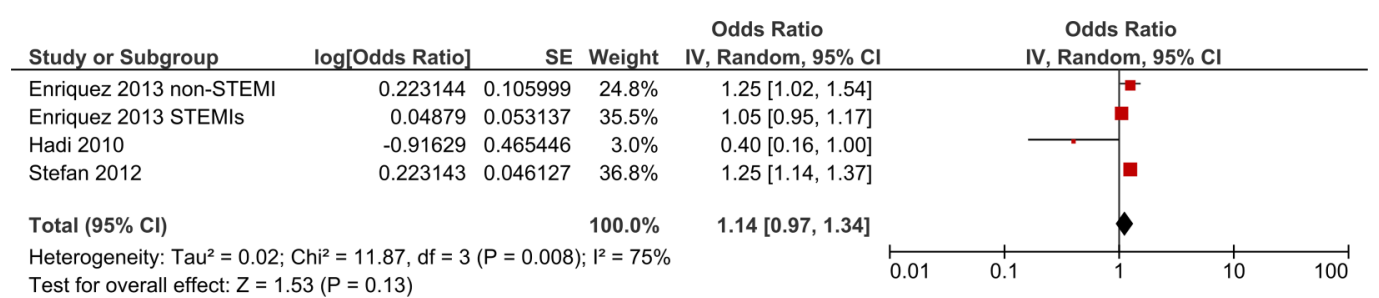

Figure 7 Forest plot showing risk of in-hospital death following Ml for patients with COPD compared to patients without COPD. Cls may vary slightly from those quoted in tables due to transformation during meta-analysis. COPD, chronic obstructive pulmonary disease; $\mathrm{Ml}$, myocardial infarction.

it is unclear how much of this increased risk is due to smoking status. The included cohort study which adjusted for smoking status showed an increased risk of MI in people with COPD, but this was not apparent in pooled analysis of the case-control studies which adjusted for smoking status. Both of the included studies which investigated the risk of MI associated with AECOPD found an increased risk of MI in the weeks following AECOPD. Most studies which investigated mortality after an MI for patients with COPD as compared to patients without COPD found that mortality after discharge was greater for those with COPD, and an increased risk of death was found on pooled analysis. However, findings on in-hospital mortality after an MI were mixed, and there was only weak evidence for increased risk of death in hospital for patients with COPD on pooled analysis.

\section{Limitations of included studies and future work}

One common limitation among the included studies, particularly those which investigated the risk of MI associated with COPD, was missing information on smoking status. As smoking is very strongly associated with COPD and risk of MI, it is likely to be a major confounder in all studies investigating this association. All of the studies in this review which investigated this association used either clinical or administrative routine data sources. Routine data are a potentially rich source of information about huge numbers of patients. However, data on smoking are not routinely recorded in all administrative databases. Indeed, all of those studies which did not have data for smoking in this question used administrative databases. Future studies on the association between COPD and cardiovascular disease should use data sources which contain reliable information on smoking status.

Further studies should be carried out to confirm findings that AECOPD are periods of increased risk of MI for people with COPD. These studies should ensure they use validated exposure measures and are adequately powered. Possible reasons for an increased risk of MI during AECOPD include increased inflammation and the potential cardiovascular effects of the drugs used to treat AECOPD. If indeed the finding of increased risk during AECOPD is confirmed, future studies should attempt to disentangle the reasons for increased risk of MI. In addition, studies should investigate factors which might modify this relationship, such as drugs used for treatment of COPD and cardiovascular prevention. Another potential bias in studies which investigate the relationship between AECOPD and MI, which could explain some of the increased risk of MI after AECOPD, is differential misclassification of episodes of angina as AECOPD.

No studies were found which investigated the risk of MI associated with the frequent exacerbator phenotype. The frequent exacerbator phenotype may prove to be a useful characteristic for stratifying cardiovascular risk among patients with COPD. Future cohort studies of cardiovascular disease in people with COPD should, where possible, phenotype participants and investigate the relationship between exacerbator phenotype and risk of MI. Few included studies assessed the influence of severity of $\mathrm{COPD}$ on risk of MI; further research should investigate

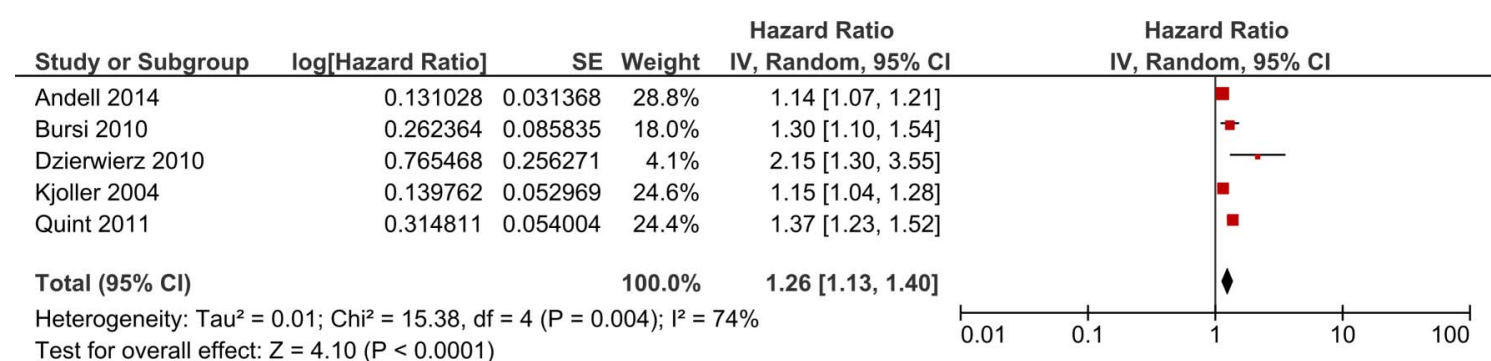

Figure 8 Forest plot showing risk of death after discharge following Ml for patients with COPD compared to patients without COPD. Cis may vary slightly from those quoted in tables due to transformation during meta-analysis. COPD, chronic obstructive pulmonary disease; MI, myocardial infarction. 
this relationship as well as the influence of severity of COPD on risk of death following MI.

A further limitation of several of the included studies on death following MI was availability of information on cause of death. Collection of information on cause of death in future studies would allow investigators to draw more confident conclusions about the reasons for increased risk of death following MI for people with COPD.

\section{Strengths and limitations of this review}

This review benefitted from using a comprehensive search strategy which covered several bibliographic databases. As the relationship between AECOPD and MI has not been extensively studied, the inclusion criteria for this research question were kept purposively broad. This allowed all information pertaining to this relationship to be included in the evidence synthesis. One potential limitation of systematic reviews is publication bias. The potential for publication bias was highest for the review of outcomes after MI. In order to reduce the risk of this bias, we only included studies which specifically investigated the risk of COPD on MI rather than several different potential prognostic factors, as studies which investigated several factors which did not find an association between COPD and MI may not have reported this in the abstract or even in the text. Owing to clinical and statistical heterogeneity, meta-analysis could only be conducted for some of the research questions. Where meta-analysis was conducted, statistical heterogeneity was generally high, and this may limit the generalisability of pooled estimates.

\section{CONCLUSIONS}

There is good evidence of an increased risk of MI in people with COPD; however, it is unclear to what extent this association is due to smoking status.

There is some evidence that among people with COPD, AECOPD represent periods of increased risk of MI. However, further larger studies using validated exposure methods are needed to support this finding.

There is weak evidence that in-hospital mortality is higher for people with COPD after an MI. There is good evidence that postdischarge mortality after an MI is higher for people with COPD.

Contributors KJR, LS and JKQ conceived and designed the study. KJR and RY screened abstracts and full text articles for inclusion, extracted data, and assessed the risk of bias of included studies. KJR conducted the metaanalysis. KJR, RY, LS and JKQ interpreted findings. KJR wrote the first draft. $\mathrm{KJR}, \mathrm{RY}, \mathrm{LS}$ and JKQ revised the article critically for important intellectual content. KJR, RY, LS and JKQ approved the final version of the article.

Funding JKQ is supported by an MRC Population Health Scientist fellowship [G0902135]. LS is supported by a Wellcome Trust Senior Research Fellowship in Clinical Science [098504/Z/12/Z].

Competing interests JKQ reports grants from Medical Research Council, grants from GSK - MRC and the British Lung Foundation during the conduct of the study; personal fees from GSK, Almirall and AstraZeneca, outside the submitted work. LS reports grants from Wellcome Trust during the conduct of the study; grants from Wellcome Trust, grants from MRC, grants from NIHR, personal fees from GSK, outside the submitted work. KJR has no conflicts of interest to disclose. RY has no conflicts of interest to disclose.

Provenance and peer review Not commissioned; externally peer reviewed.

Data sharing statement This is a systematic review of previously published studies.

Open Access This is an Open Access article distributed in accordance with the terms of the Creative Commons Attribution (CC BY 4.0) license, which permits others to distribute, remix, adapt and build upon this work, for commercial use, provided the original work is properly cited. See: http:// creativecommons.org/licenses/by/4.0/

\section{REFERENCES}

1. Sin DD, Anthonisen NR, Soriano JB, et al. Mortality in COPD: role of comorbidities. Eur Respir J 2006;28:1245-57.

2. Curkendall SM, DeLuise C, Jones JK, et al. Cardiovascular disease in patients with chronic obstructive pulmonary disease, Saskatchewan Canada cardiovascular disease in COPD patients. Ann Epidemiol 2006;16:63-70.

3. Feary JR, Rodrigues LC, Smith CJ, et al. Prevalence of major comorbidities in subjects with COPD and incidence of myocardial infarction and stroke: a comprehensive analysis using data from primary care. Thorax 2010;65:956-62.

4. Schneider C, Bothner U, Jick SS, et al. Chronic obstructive pulmonary disease and the risk of cardiovascular diseases. Eur $J$ Epidemiol 2010;25:253-60.

5. Divo M, Cote C, de Torres JP, et al. Comorbidities and risk of mortality in patients with chronic obstructive pulmonary disease. Am $J$ Respir Crit Care Med 2012;186:155-61.

6. Mannino DM, Thorn D, Swensen A, et al. Prevalence and outcomes of diabetes, hypertension and cardiovascular disease in COPD. Eur Respir J 2008;32:962-9.

7. Pitta F, Troosters T, Spruit MA, et al. Characteristics of physical activities in daily life in chronic obstructive pulmonary disease. Am J Respir Crit Care Med 2005;171:972-7.

8. Sin DD, Wu L, Man SF. The relationship between reduced lung function and cardiovascular mortality*: a population-based study and a systematic review of the literature. Chest 2005;127:1952-9.

9. Donaldson GC, Hurst JR, Smith CJ, et al. Increased risk of myocardial infarction and stroke following exacerbation of COPD. Chest 2010;137:1091-7.

10. Andell P, Koul S, Martinsson A, et al. Impact of chronic obstructive pulmonary disease on morbidity and mortality after myocardial infarction. Open Heart 2014;1:e000002.

11. Enriquez JR, de Lemos JA, Parikh SV, et al. Association of chronic lung disease with treatments and outcomes patients with acute myocardial infarction. Am Heart J 2013;165:43-9.

12. Raposeiras Roubin S, Abu Assi E, Alvarez Alvarez B, et al. In-hospital and follow-up mortality associated to chronic obstructive pulmonary disease in a contemporary cohort of patients with acute coronary syndrome. Eur Heart $J$ 2012;33:1084

13. Kjoller $\mathrm{E}$, Kober $\mathrm{L}$, Iversen $\mathrm{K}$, et al. Importance of chronic obstructive pulmonary disease for prognosis and diagnosis of congestive heart failure in patients with acute myocardial infarction. Eur $J$ Heart Fail 2004:6:71-7.

14. Stefan MS, Bannuru RR, Lessard D, et al. The impact of COPD on management and outcomes of patients hospitalized with acute myocardial infarction: a 10-year retrospective observational study. Chest 2012;141:1441-8.

15. Hadi HA, Zubaid M, Al Mahmeed W, et al. Prevalence and prognosis of chronic obstructive pulmonary disease among 8167 Middle Eastern patients with acute coronary syndrome. Clin Cardiol 2010;33:228-35.

16. Wells G, Shea B, O'Connell D, et al. The Newcastle-Ottawa Scale (NOS) for assessing the quality of nonrandomised studies in meta-analyses. Secondary The Newcastle-Ottawa Scale (NOS) for assessing the quality of nonrandomised studies in meta-analyses. http://www.ohri.ca/programs/clinical_epidemiology/oxford.asp

17. Jüni $P$, Witschi $A$, Bloch $R$, et al. The hazards of scoring the quality of clinical trials for meta-analysis. JAMA 1999;282:1054-60.

18. Higgins J, Green S. Cochrane handbook for systematic reviews of interventions. Chichester, UK: John Wiley \& Sons Ltd., 2008.

19. Rodriguez LA, Wallander MA, Martin-Merino E, et al. Heart failure, myocardial infarction, lung cancer and death in COPD patients: a UK primary care study. Respir Med 2010;104:1691-9. 
20. Huiart L, Ernst P, Suissa S. Cardiovascular morbidity and mortality in COPD. Chest 2005;128:2640-6.

21. Halpin DM, Decramer M, Celli B, et al. Risk of nonlower respiratory serious adverse events following COPD exacerbations in the 4-year UPLIFT Trial. Lung 2011;189:261-8.

22. Behar S, Panosh A, Reicher-Reiss $\mathrm{H}$, et al. Prevalence and prognosis of chronic obstructive pulmonary disease among 5,839 consecutive patients with acute myocardial infarction. SPRINT Study Group. Am J Med 1992;93:637-41.

23. Bursi F, Vassallo R, Weston SA, et al. Chronic obstructive pulmonary disease after myocardial infarction in the community. Am Heart J 2010;160:95-101.

24. Dziewierz A, Siudak Z, Rakowski T, et al. Relationship between chronic obstructive pulmonary disease and in-hospital management and outcomes in patients with acute myocardial infarction. Kardiol Pol 2010;68:294-301.

25. Hawkins NM, Huang Z, Pieper KS, et al. Chronic obstructive pulmonary disease is an independent predictor of death but not atherosclerotic events in patients with myocardial infarction: analysis of the Valsartan in Acute Myocardial Infarction Trial (VALIANT). Eur J Heart Fail 2009;11:292-8.

26. Quint JK, Herrett E, Timmis A, et al. Survival after the first myocardial infarction is shorter in patients with COPD compared to the general population. Thorax 2011;66:A45-6.
27. Salisbury AC, Reid KJ, Spertus JA. Impact of chronic obstructive pulmonary disease on post-myocardial infarction outcomes. Am J Cardiol 2007;99:636-41.

28. Mapel DW, Dedrick D, Davis K. Trends and cardiovascular co-morbidities of COPD patients in the veterans administration medical system, 1991-1999. COPD 2005;2:35-41.

29. Sidney S, Sorel M, Quesenberry CP Jr, et al. COPD and incident cardiovascular disease hospitalizations and mortality: Kaiser Permanente Medical Care Program. Chest 2005;128:2068-75.

30. Curkendall SM, Lanes S, de Luise $\mathrm{C}$, et al. Chronic obstructive pulmonary disease severity and cardiovascular outcomes. Eur $J$ Epidemiol 2006;21:803-13.

31. Sode BF, Dahl M, Nordestgaard BG. Myocardial infarction and other co-morbidities in patients with chronic obstructive pulmonary disease: a Danish nationwide study of 7.4 million individuals. Eur Heart J 2011;32:2365-75.

32. Yin L, Lensmar C, Ingelsson E, et al. Differential association of chronic obstructive pulmonary disease with myocardial infarction and ischemic stroke in a nation-wide cohort. Int $\mathrm{J}$ Cardiol 2014;173:601-3.

33. Rha SW, Li YJ, Chen KY, et al. Impact of chronic obstructive pulmonary disease on the clinical characteristics and outcomes in propensity-matched patients with acute myocardial infarction. $A m \mathrm{~J}$ Cardiol 2009;103:36-37B. 